\title{
Howardella ureilytica gen. nov., sp. nov., a Gram- positive, coccoid-shaped bacterium from a sheep rumen
}

\author{
Correspondence \\ Paul W. Riley \\ paul.riley@hpa.org.uk
}

\author{
Anthony R. Cook, ${ }^{1}$ Paul W. Riley, ${ }^{1}$ Heather Murdoch, ${ }^{1} \dagger$ Paul N. Evans ${ }^{2}$ \\ and lan R. McDonald ${ }^{3}$
${ }^{1}$ Health Protection Agency, Centre for Emergency Preparedness and Response, Porton Down, Salisbury SP4 OJG, UK Palmerston North 4442, New Zealand
${ }^{3}$ Department of Biological Sciences, University of Waikato, Private Bag 3105, Hamilton 3240, New Zealand \\ ${ }^{2}$ Rumen Biotechnology, AgResearch, Grasslands Research Centre, Private Bag 11008,
}

\begin{abstract}
An unidentified obligately anaerobic, fastidious, Gram-positive, non-motile, non-spore-forming, non-fermentative coccoid-shaped bacterium (designated strain GPC $589^{\top}$ ) was isolated from the rumen fluid of a sheep. The major fatty acid constituents $(>5 \%)$ were $\mathrm{C}_{16: 0}(29.2 \%), \mathrm{C}_{18: 0}$ $(40.7 \%)$ and an unidentified compound (19.7\%) with an equivalent chain-length of 13.523 . The $\mathrm{G}+\mathrm{C}$ content of the DNA was $34 \mathrm{~mol} \%$. The organism was strongly ureolytic and generated ATP through the hydrolysis of urea. Comparative 16S rRNA gene sequence analysis demonstrated that strain GPC $589^{\top}$ was far removed, phylogenetically, from the ruminococci and related Gram-positive anaerobic cocci but exhibited a phylogenetic association with Clostridium rRNA cluster XIVa [as defined by Collins, M. D., Lawson, P. A., Willems, A., Cordoba, J. J., Fernandez-Garayzabal, J., Garcia, P., Cai, J., Hippe, H. \& Farrow, J. A. E. (1994). Int J Syst Bacterio/ 44, 812-826]. Sequence divergence values of $12.5 \%$ or more were observed between strain GPC $589^{\top}$ and all other recognized species within this and related rRNA clostridial clusters. Phylogenetic analysis showed that strain GPC $589^{\top}$ represents a new genus within cluster $\mathrm{XIVa}$. On the basis of both phylogenetic and phenotypic evidence, it is proposed that strain GPC $589^{\top}$ should be classified as representing a new genus and novel species, Howardella ureilytica gen. nov., sp. nov. The type strain is strain GPC $589^{\top}\left(=\mathrm{DSM} 15118^{\top}=\mathrm{JCM} 13267^{\top}\right)$.
\end{abstract}

In the ruminant herbivore, primary digestion of the food is carried out by the micro-organisms of the rumen. For many of the ruminal bacteria, ammonia is the major nitrogen source. Urea is present in ruminant saliva and diffuses into the rumen through the rumen wall and, as urea is rapidly hydrolysed in the rumen (Pearson \& Smith, 1943), it is an important source of ammonia especially in the recycling of nitrogen in the rumen. While urea is physiologically important to nitrogen metabolism in ruminants, it is also economically important to ruminant feeding. However, the microbial aspects of urea metabolism are not well understood, either regarding numbers relative to total rumen bacteria or whether the ureolytic

tPresent address: Infection Control Team, Health Protection Scotland, 1 Cadogan Square, Cadogan Street, Glasgow G2 7HF, UK.

Abbreviation: ECL, equivalent chain-length.

The GenBank/EMBL/DDBJ accession number for the 16S rRNA gene sequence of strain GPC $589^{\top}$ is DQ.925472. bacteria are widespread in rumen contents, or even whether bacteria are the major source of rumen urease (Farlin et al., 1968).

Strain GPC $589^{\mathrm{T}}$ was isolated from the rumen fluid of a penned cannulated sheep that had been fed on a diet of hay and grass with water ad libitum. The anaerobic culture technique of Hungate (1950) was used with oxygen-free $\mathrm{CO}_{2}$ as the gas phase and incubation at $37^{\circ} \mathrm{C}$. Initially, a fresh rumen fluid sample $(0.5 \%, \mathrm{v} / \mathrm{v})$ was enriched for $48 \mathrm{~h}$ (Cook, 1976) in medium GM comprising (w/v): Bacto casitone $(0.5 \%)$, Bacto yeast extract $(0.5 \%), \mathrm{KH}_{2} \mathrm{PO}_{4}$ $(0.25 \%), \quad \mathrm{Na}_{2} \mathrm{HPO}_{4} \quad(0.25 \%), \quad \mathrm{CH}_{3} . \mathrm{COONa} \quad(0.1 \%)$, mannitol $(0.2 \%), \mathrm{MgCl}_{2} \cdot 6 \mathrm{H}_{2} \mathrm{O}(0.05 \%)$, sodium thioglycollate $(0.075 \%)$ and resazurin $(0.0001 \%), \mathrm{pH} 7.0$; autoclaved at $103.5 \mathrm{kPa}$ for $15 \mathrm{~min}$. Filter-sterilized urea $(0.2 \% \mathrm{w} / \mathrm{v}$, final concentration) was added to cooled medium. The enrichment was maintained by overnight subculturing $(0.1 \mathrm{ml})$ in $8 \mathrm{ml}$ medium $\mathrm{G}$ (mannitol-free GM) in Hungate tubes. An ureolytic Gram-positive coccus 
was isolated from a Hungate roll tube of medium GM (4.5 ml containing $2 \%$ agar) that had been inoculated $(0.5 \mathrm{ml})$ from the $10^{-7}$ dilution of a decimal dilution series (medium G) of an overnight subculture; this was identified presumptively as an enterococcus. After overnight incubation (about $18 \mathrm{~h}$ ) in medium $\mathrm{G}$, a decimal dilution series showed a hazy growth in the $10^{-9}$ dilution in contrast to the heavy growth present at lower dilutions: there was no visible growth in the higher dilutions. Over a 3-day incubation period during which time the ureolytic activity of this $10^{-9}$ dilution culture increased, there was no discernible increase in turbidity. The Gram-positive isolate from the $10^{-9}$ dilution tube was designated strain GPC $589^{\mathrm{T}}$. Urease activity was determined by measuring ammonia production in the presence and absence of urea. A $1 \mathrm{ml}$ centrifuged sample of a broth culture was resuspended in an equal volume of $20 \mathrm{mM}$ sodium phosphate buffer ( $\mathrm{pH} 7.0$ ) containing $1 \mathrm{mM}$ EDTA. A $25 \mu \mathrm{l}$ sample was incubated with $0.17 \mathrm{mmol}$ urea in a final volume of $1 \mathrm{ml}$ for $5 \mathrm{~min}$ at $37^{\circ} \mathrm{C}$. The reaction was terminated by the addition of phenate-hypochlorite reagents (Weatherburn, 1967), modified such that $1 \mathrm{ml}$ of each reagent was used in an assay. The colour was developed for $25 \mathrm{~min}$ at $37^{\circ} \mathrm{C}$ and read at $570 \mathrm{~nm}$. Culture growth was measured by determining the viable count as turbidities were too low. Viable counts of cultures were carried out within the oxygen-free atmosphere of a flexiblefilm anaerobic chamber, using procedures described by Hartley et al. (1992). BHF plates of supplemented brain heart infusion blood agar (Barr et al., 1987), stored anaerobically $\left(10 \% \mathrm{CO}_{2}, 10 \% \mathrm{H}_{2}\right.$ in $\left.\mathrm{N}_{2},>90 \% \mathrm{RH}\right)$ at $4{ }^{\circ} \mathrm{C}$, were lightly air-dried at $37{ }^{\circ} \mathrm{C}$ before being transferred to the anaerobic chamber for overnight storage. The source of brain heart infusion used in this medium (Oxoid) was found to be important: other sources were inferior (data not shown). The agar medium was inoculated with triplicate $25 \mu \mathrm{l}$ samples of a decimal dilution series of a culture prepared in brain heart infusion broth using a modification of the technique of Miles et al. (1938), as described previously by Hudson et al. (1984). The plates were removed from the chamber and incubated anaerobically at $37^{\circ} \mathrm{C}$ for $72 \mathrm{~h}$ (Hartley et al., 1992). Gram staining was based on the method of Preston \& Morrell (1962) but with modifications to the iodine mordant (Magee et al., 1975), the safranin counterstain (Holdeman et al., 1977) and the use of acetone to fix the air-dried slides (Mangels et al., 1984). Following publication of the procedure of Johnson et al. (1995), staining was done anaerobically to ensure uniformity of stain. Cell morphology was observed using a Leitz Dialux light microscope at a magnification of $\times 1000$ with cells grown in medium $G$ overnight at $37^{\circ} \mathrm{C}$.

Strain GPC $589^{\mathrm{T}}$ was characterized biochemically by using a combination of conventional tests as described in the VPI Anaerobe Laboratory Manual (Holdeman et al., 1977). All biochemical tests were performed in triplicate. The following compounds did not augment the growth of strain GPC $589^{\mathrm{T}}$ when added to medium $\mathrm{G}$ and grown anaerobically at $37{ }^{\circ} \mathrm{C}$ : carbohydrates: glucose, sucrose, maltose, starch, mannitol and cellobiose; carboxylic compounds: pyruvate, lactate, malate, formate, fumarate, succinate and citrate; Tween 80 ; mixture of volatile fatty acids (propionic, n-butyric, n-valeric, iso-butyric, 3methylbutyric and 2-methylbutyric; Holdeman et al., 1977); nitrogen compounds (urea omitted): ammonia and nitrate; haemin; serum; vitamin $\mathrm{K}$ and bicarbonate. The following were required for optimum growth: casitone, yeast extract, acetate, magnesium, sodium/ potassium phosphate, thioglycollate and urea. Thioglycollate was required for a reduced environment; cysteine was inhibitory. Acetate stimulated growth. Urea was demonstrated to be essential for growth of strain GPC $589^{\mathrm{T}}$; the minimal growth in medium without urea (Bacto casitone is a milk product and contains trace amounts of urea) contrasts with the 140 -fold increase in the presence of urea at $0.2 \%(\mathrm{w} / \mathrm{v})$. Whereas urea was essential for growth, ammonia, a product of the strong urease activity, did not support growth. The role for the hydrolysis of urea was to generate ATP. Thus, preincubation of strain GPC $589^{\mathrm{T}}$ with the urease inhibitor fluorofamide (Millner et al., 1982; Kenny, 1983) resulted in an $87 \%$ inhibition of ammonia production and a concomitant $92 \%$ reduction in ATP synthesis. Strain GPC $589^{\mathrm{T}}$ did not grow at 20 or $50{ }^{\circ} \mathrm{C}$. The $\mathrm{G}+\mathrm{C}$ content of the DNA was determined by HPLC as described by Ezaki et al. (1990). DNA from peptostreptococci (Peptostreptococcus asaccharolyticus, Peptostreptococcus prevotii and Peptostreptococcus magnus), ruminococci (Ruminococcus torques and Ruminococcus obeum) and Peptococcus niger was used for reference. The $\mathrm{G}+\mathrm{C}$ content of the DNA of strain GPC $589^{\mathrm{T}}$ was found to be $34 \mathrm{~mol} \%$, which was consistent with the assignment of this isolate to the low $\mathrm{G}+\mathrm{C}$ branch of the Gram-positive bacteria.

Fatty acid methyl esters were obtained from $40 \mathrm{mg}$ cells scraped from Petri dishes by saponification, methylation and extraction, using minor modifications of the methods of Miller (1982) and Kuykendall et al. (1988). The fatty acid methyl ester mixtures were separated using the Sherlock Microbial Identification System (MIS) (MIDI, Microbial ID), which consisted of an Agilent model 6890N gas chromatograph fitted with a $5 \%$ phenyl-methylsilicone capillary column $(0.2 \mathrm{~mm} \times 25 \mathrm{~m})$, a flameionization detector, Agilent model 7683A automatic sampler and an HP-computer with MIDI database (Hewlett Packard Co.). Peaks were integrated automatically and fatty acid names and percentages were calculated using the MIS standard software (Microbial ID). The gas chromatographic parameters were as follows: carrier gas, ultra-high-purity hydrogen; column head pressure, $60 \mathrm{kPa}$; injection volume, $2 \mu \mathrm{l}$; column split ratio, 100 : 1; septum purge, $5 \mathrm{ml} \mathrm{min}^{-1}$; column temperature, $170-270{ }^{\circ} \mathrm{C}$ at $5{ }^{\circ} \mathrm{C} \min ^{-1}$; injection port temperature, $240{ }^{\circ} \mathrm{C}$; and detector temperature, $300{ }^{\circ} \mathrm{C}$ (Kämpfer \& Kroppenstedt, 1996). The cellular fatty acid composition of strain GPC 
$589^{\mathrm{T}}$ consisted of straight-chain saturated and unsaturated fatty acids. The principal fatty acids were the saturated acids $\mathrm{C}_{16: 0}(29.2 \%)$ and $\mathrm{C}_{18: 0}(40.7 \%)$. There were also smaller amounts of the saturated fatty acids $\mathrm{C}_{14: 0}(0.7 \%)$ and $\mathrm{C}_{17: 0}(1.7 \%)$. The unsaturated acids $\mathrm{C}_{16: 1} \omega 9 c(2.4 \%)$, $\mathrm{C}_{18: 1} \omega 9 c(4.5 \%)$ and $\mathrm{C}_{18: 1} \omega 11 c(1.1 \%)$ were also present. An unidentified compound with an equivalent chainlength (ECL) of 13.523 was detected (19.7\%), but could not be assigned to a known fatty acid or a dimethylacetal.

The 16S rRNA gene sequence was determined from the isolated DNA (Luton et al., 2002) using the primers of Hutson et al. (1993) and PCR was performed using the protocol of Innis \& Gelfand (1990). The 16S rRNA gene was amplified by PCR using the universal eubacterial primers (Lane, 1991). Sequenced 16S rRNA gene fragments were assembled into one contiguous sequence. Phylogenetic analysis was performed using the software packages PHYLIP (Felsenstein, 1993) and TreeView (Page, 1996), after alignment of data using ARB (Ludwig et al., 2004). Distances (Kimura two-parameter model) and clustering by neighbour-joining methods were determined by using bootstrap values based on 1000 replicates (Fig. 1). The 16S rRNA gene sequence of strain GPC $589^{\mathrm{T}}$ was a continuous stretch of 1531 bp. Sequence database searches showed that strain GPC $589^{\mathrm{T}}$ displayed the highest sequence relatedness to members of the Clostridium subphylum (data not shown), consistent with the low $\mathrm{G}+\mathrm{C}$ content. On the basis of sequence similarities, the closest named relatives of strain GPC $589^{\mathrm{T}}$ corresponded to species within Clostridium rRNA cluster XIVa (see Collins et al., 1994, for rRNA group designations). Sequence similarity calculations indicated that the closest relatives of strain GPC $589^{\mathrm{T}}$ were Catonella morbi ATCC $51271^{\mathrm{T}}$ (86.5\%), Johnsonella ignava ATCC $51276^{\mathrm{T}}(85.3 \%)$ (these were placed in cluster XIVa by Willems \& Collins, 1995), Eubacterium saburreum C27KA (87.4\%), Clostridium polysaccharolyticum DSM $1801^{\mathrm{T}}(88.3 \%)$, Acetitomaculum ruminis $139 \mathrm{~B}^{\mathrm{T}}(87.2 \%)$ and Eubacterium hallii ATCC
$27751^{\mathrm{T}}(87.5 \%)$. These bacteria were isolated from such diverse habitats as the human buccal cavity, the rumen and human faeces. The monospecific genera Catonella and Johnsonella, described by Moore \& Moore (1994), were isolated from the human gingival crevice and periodontal pockets (Moore et al., 1985) and were originally referred to as 'Bacteroides D42' and 'Bacteroides D19', respectively. Holdeman \& Moore (1974) described E. hallii, which was isolated from human faecal flora. A. ruminis was isolated from the bovine rumen and described by Greening \& Leedle (1989). In 1980, van Glyswyk isolated Fusarium polysaccharolyticum from the sheep rumen, which was later renamed Clostridium polysaccharolyticum (van Gylswyk et al., 1980). The description of the anaerobic filamentous micro-organisms isolated from human dental plaque and gingival crevices but unnamed by Theilade \& Gilmour (1961) was used by Holdeman et al. (1977) in their description of E. saburreum (Skerman et al., 1980). A BLAST search using the 16S rRNA gene of strain GPC $589^{\mathrm{T}}$ revealed that uncultured bacterial clones have been identified from humans, which are closer to strain GPC $589^{\mathrm{T}}$ than the species in Clostridium rRNA cluster XIVa. Ley et al. (2006) identified two clones, RL249 (GenBank accession no. DQ805137) and RL181 (DQ798309) from human faeces and Eckburg et al. (2005) identified clone MH95 (AY982262) from a biopsy of the human colon mucosa and a further three clones from biopsies of the human colon, MG76 (AY982192), LY31 (AY976352) and MG71 (AY916289).

From the data presented, it is evident that the Grampositive, asporogenous, coccoid-shaped strain GPC $589^{\mathrm{T}}$, recovered from a sheep rumen, represents an unknown line within the Clostridium subphylum of the Gram-positive bacteria (Collins et al., 1994). Phylogenetically, strain GPC $589^{\mathrm{T}}$ has an affinity with rRNA cluster XIVa, but not with the Gram-positive anaerobic cocci that are interspersed throughout a variety of phylogenetic groups. The association of strain GPC $589^{\mathrm{T}}$ with members of Clostridium

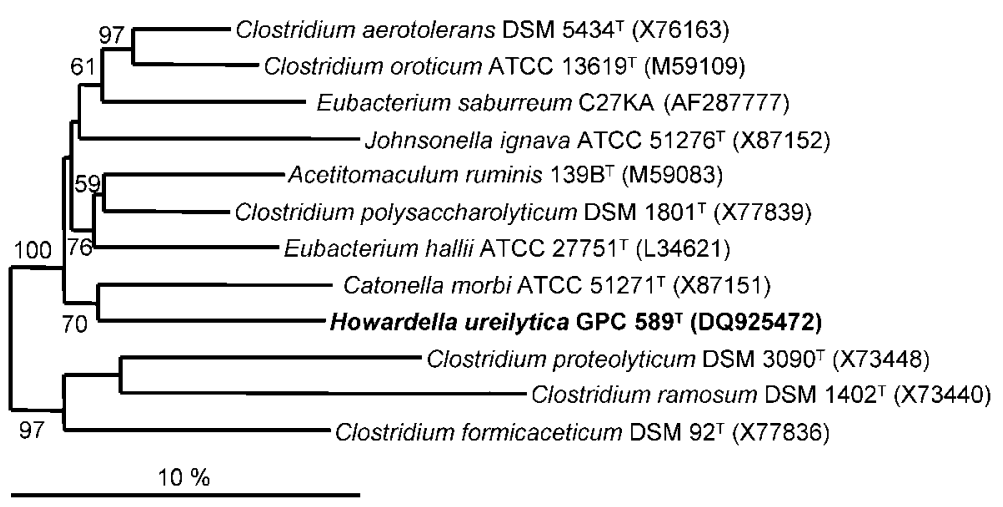

Fig. 1. Phylogenetic tree based on analysis of the 16S rRNA gene sequences of strain GPC $589^{\top}$, representative species within cluster $\mathrm{XIVa}$ of the Clostridium subphylum, and representatives of other clusters of the Clostridium subphylum showing the position of the novel genus Howardella. The dendrogram was produced with DNADIST (neighbourjoining) analysis using $1317 \mathrm{bp}$ of aligned sequence. The phylogenetic tree was rooted to Clostridium butyricum ATCC $19398^{\top}$ (GenBank accession no. M59085; not shown). Bootstrap values above $50 \%$ are shown from 1000 replicates. Bar, 10\% sequence divergence. 
rRNA group XIVa was only loose, with strain GPC $589^{\mathrm{T}}$ branching deeply at the periphery of the cluster. Treeing analysis showed that strain GPC $589^{\mathrm{T}}$ did not have a close relationship with any individual member of Clostridium rRNA group XIVa, although the branching at the base of the grouping was supported by a high bootstrap value. The distinctiveness of strain GPC $589^{\mathrm{T}}$ was also evident from divergence values of greater than $12 \%$ with members of rRNA cluster XIVa and of greater than $20 \%$ with other recognized Gram-positive anaerobic cocci.

Clostridium rRNA cluster XIVa embraces a diverse range of organisms including Catonella morbi, J. ignava, E. hallii, A. ruminis, E. saburreum and a variety of clostridial species, Clostidium aerotolerans, Clostridium oroticum, Clostridium polysaccharolyticum, Clostridium proteolyticum, Clostridium ramosum and Clostridium formicaceticum. In addition to high sequence divergence values and tree topology considerations, support for the separateness of strain GPC $589^{\mathrm{T}}$ from other organisms within Clostridium rRNA cluster XIVa also comes from phenotypic considerations (Table 1). In particular, strain GPC $589^{\mathrm{T}}$ can be readily distinguished from all other taxa within this cluster by its small, coccoid cells and the synthesis of ATP from the hydrolysis of urea. Furthermore, strain GPC $589^{\mathrm{T}}$ can be distinguished from Clostridium polysaccharolyticum by not producing endospores. The non-fermentative characteristic distinguishes strain GPC $589^{\mathrm{T}}$ from Catonella morbi, E. hallii, E. saburreum and A. ruminis. The phenotypic distinctiveness of strain GPC $589^{\mathrm{T}}$, together with its long rRNA line branching at the base of Clostridium rRNA cluster XIVa, merits its inclusion in a new genus and species, Howardella ureilytica gen. nov., sp. nov.

\section{Description of Howardella gen. nov.}

Howardella (Ho.war.del'la. N.L. fem. dim. Howardella to honour the New Zealand microbiologist Bernard Howard, in recognition of his many contributions to anaerobic microbiology).

Gram-positive-staining, non-spore-forming, non-motile, coccoid cells. Growth occurs under strictly anaerobic conditions. Carbohydrates are not fermented. Nitrate is not reduced. Acetate stimulates growth. Member of the Clostridium subphylum of the Gram-positive bacteria and is phylogenetically loosely associated with Clostridium rRNA group XIVa. The type species is Howardella ureilytica.

\section{Description of Howardella ureilytica sp. nov.}

Howardella ureilytica (u.re.i.ly'ti.ca. N.L. n. urea urea; Gr. adj. lutikos able to dissolve; N.L. adj. lyticus -a -um dissolving; N.L. fem. adj. ureilytica urea dissolving).

Exhibits the following properties in addition to those given in the genus description. Cells are $0.77-0.83 \mu \mathrm{m}$ long $\times 0.61-0.67 \mu \mathrm{m}$ wide and occur singly, in pairs, although occasionally in short chains of $6-8$ cells. After $72 \mathrm{~h}$ anaerobic incubation at $37^{\circ} \mathrm{C}$ under a gas phase of $\mathrm{N}_{2}, \mathrm{CO}_{2}$ and $\mathrm{H}_{2}(80: 10: 10$, by vol.) on BHF/blood agar, colonies are minute to $1 \mathrm{~mm}$ in diameter, circular, entire, domed and white. Urea is obligatory. Carbohydrates are not fermented. Hydrolysis of urea by cytostolic urease generates ATP. Long-chain cellular fatty acids consist of a complex mixture including an unknown with an ECL of 13.523, $\mathrm{C}_{16: 0}$ and $\mathrm{C}_{18: 0}$. The $\mathrm{G}+\mathrm{C}$ content of the DNA of the type strain is $34 \mathrm{~mol} \%$. Habitat, gastrointestinal tract.

Table 1. Differential characteristics of strain GPC $589^{\top}$ (Howardella ureilytica gen. nov., sp. nov.) and phylogenetically closely related species

Strains: 1, strain GPC $589^{\mathrm{T}}$; 2, Catonella morbi ATCC $51271^{\mathrm{T}}$ (data from Moore \& Moore, 1994; Moore et al., 1985); 3, J. ignava ATCC 51276 ${ }^{\mathrm{T}}$ (Moore \& Moore, 1994; Moore et al., 1985); 4, E. saburreum C27KA (Theilade \& Gilmour, 1961; Holdeman et al., 1977; Skerman et al., 1980); 5, E. hallii ATCC $27751^{\mathrm{T}}$ (Holdeman \& Moore, 1974); 6, A. ruminis 139B ${ }^{\mathrm{T}}$ (Greening \& Leedle, 1989); 7, Clostridium polysaccharolyticum DSM 1801 ${ }^{\mathrm{T}}$ (van Gylswyk, 1980; van Gylswyk et al., 1980). -, Negative; +/-, weak; +, positive; ND, not determined.

\begin{tabular}{|c|c|c|c|c|c|c|c|}
\hline Characteristic & 1 & 2 & 3 & 4 & 5 & 6 & 7 \\
\hline Cell size $(\mu \mathrm{m})$ & $0.61-0.67$ & $0.7-1.2$ & 0.8 & $0.7-1.1$ & $0.8-2.4$ & $0.8-1.0$ & $0.6-1.1$ \\
\hline Motility & - & - & - & - & - & $+1-$ & + \\
\hline Spore formation & - & - & - & - & - & - & + \\
\hline \multicolumn{8}{|l|}{ Utilization of: } \\
\hline Glucose & - & + & - & + & + & + & $\mathrm{ND}$ \\
\hline Maltose & - & + & - & $+1-$ & + & - & - \\
\hline Starch & - & - & - & - & - & - & + \\
\hline Sucrose & - & + & - & + & - & $\mathrm{ND}$ & - \\
\hline DNA G $+\mathrm{C}$ content $(\mathrm{mol} \%)$ & 34 & 34 & 32 & $\mathrm{ND}$ & 38 & $32-36$ & 42 \\
\hline
\end{tabular}


The type strain, GPC $589^{\mathrm{T}}\left(=\mathrm{DSM} 15118^{\mathrm{T}}=\mathrm{JCM} 13267^{\mathrm{T}}\right)$, was isolated from a sheep rumen.

\section{Acknowledgements}

We are grateful to Norwich-Eaton Pharmaceuticals (Norwich, NY, USA) for the gift of fluorofamide ( $N$-[diaminophosphinyl]-4fluorobenzamide), to H. Trüper, J. Euzéby and E. Falsen for support with the nomenclature and to R. M. Kroppenstedt (DSMZ) who supplied the cellular fatty acid data.

\section{References}

Barr, G. D., Hudson, M. J., Priddle, J. D. \& Jewell, D. P. (1987). Colonic bacterial proteases to $\operatorname{IgA}_{1}$ and $\operatorname{sgA}$ in patients with ulcerative colitis. Gut 28, 186-189.

Collins, M. D., Lawson, P. A., Willems, A., Cordoba, J. J., FernandezGarayzabal, J., Garcia, P., Cai, J., Hippe, H. \& Farrow, J. A. E. (1994). The phylogeny of the genus Clostridium: proposal of five new genera and eleven new species combinations. Int J Syst Bacteriol 44, 812-826.

Cook, A. R. (1976). Urease activity in the rumen of sheep and the isolation of ureolytic bacteria. J Gen Microbiol 92, 32-48.

Eckburg, P. B., Bik, E. M., Bernstein, C. N., Purdom, E., Dethlefsen, L., Sargent, M., Gill, S. R., Nelson, K. E. \& Relman, D. A. (2005). Diversity of the human intestinal microbial flora. Science 308, 1635-1638.

Ezaki, T., Saidi, S. M., Liu, S.-L., Hashimoto, Y., Yamamoto, H. \& Yabuuchi, E. (1990). Rapid procedure to determine the DNA base composition from small amounts of Gram-positive bacteria. FEMS Microbiol Lett 67, 127-130.

Farlin, S. D., Brown, R. E. \& Garrigus, U. S. (1968). In vivo metabolism of biuret and urea by sheep. J Anim Sci 27, 771-775.

Felsenstein, J. (1993). PHYLIP (phylogeny inference package), version 3.5c. Distributed by the author. Department of Genome Sciences, University of Washington, Seattle, USA.

Greening, R. C. \& Leedle, J. A. Z. (1989). Enrichment and isolation of Acetitomaculum ruminis, gen. nov., sp. nov.: acetogenic bacteria from the bovine rumen. Arch Microbiol 151, 399-406.

Hartley, M. G., Hudson, M. J., Swarbrick, E. T., Hill, M. J., Gent, A. E., Hellier, M. D. \& Grace, R. H. (1992). The rectal mucosa-associated microflora in patients with ulcerative colitis. J Med Microbiol 36, 96-103.

Holdeman, L. V. \& Moore, W. E. C. (1974). New genus, Coprococcus, twelve new species, and emended descriptions of four previously described species of bacteria from human feces. Int J Syst Bacteriol 24, 260-277.

Holdeman, L. V., Cato, E. P. \& Moore, W. E. C. (1977). Anaerobe Laboratory Manual, 4th edn. Blacksburg, VA: Virginia Polytechnic Institute and State University.

Hudson, M. J., Hill, M. J., Elliott, P. R., Berghouse, L. M., Burnham, W. R. \& Lennard-Jones, J. E. (1984). The microbial flora of the rectal mucosa and faeces of patients with Crohn's disease before and during antimicrobial chemotherapy. J Med Microbiol 18, 335-345.

Hungate, R. E. (1950). The anaerobic mesophilic cellulolytic bacteria. Bacteriol Rev 14, 1-49.

Hutson, R. A., Thompson, D. E. \& Collins, M. D. (1993). Genetic interrelationships of saccharolytic Clostridium botulinum types B, E and $\mathrm{F}$ and related clostridia as revealed by small-subunit rRNA gene sequences. FEMS Microbiol Lett 108, 103-110.

Innis, M. A. \& Gelfand, D. H. (1990). Optimization of PCRs. In PCR Protocols: A Guide to Methods and Applications, pp. 3-12. Edited by
M. A. Innis, D. H. Gelfand, J. J. Sninsky \& T. J. White. San Diego: Academic Press.

Johnson, M. J., Thatcher, E. \& Cox, M. E. (1995). Techniques for controlling variability in Gram staining of obligate anaerobes. J Clin Microbiol 33, 755-758.

Kämpfer, P. \& Kroppenstedt, R. M. (1996). Numerical analysis of fatty acid patterns of coryneform bacteria and related taxa. Can J Microbiol 42, 989-1005.

Kenny, G. E. (1983). Inhibition of the growth of Ureaplasma urealyticum by a new urease inhibitor, flurofamide. Yale J Biol Med 56, 717-722.

Kuykendall, L. D., Roy, M. A., O'Neill, J. J. \& Devine, T. E. (1988). Fatty acids, antibiotic resistance, and deoxyribonucleic acid homology groups of Bradyrhizobium japonicum. Int J Syst Bacteriol 38, 358-361.

Lane, D. J. (1991). 16S/23S rRNA sequencing. In Nucleic Acid Techniques in Bacterial Systematics, pp. 115-175. Edited by E. Stackebrandt \& M. Goodfellow. Chichester, UK: J. Wiley and Sons Ltd.

Ley, R. E., Turnbaugh, P. J., Klein, S. \& Gordon, J. I. (2006). Microbial ecology: human gut microbes associated with obesity. Nature 444, 1022-1023.

Ludwig, W., Strunk, O., Westram, R., Richter, L., Meier, H., Yadhukumar, Buchner, A., Lai, T., Steppi, S. \& other authors (2004). ARB: a software environment for sequence data. Nucleic Acids Res 32, 1363-1371.

Luton, P. E., Wayne, J. M., Sharp, R. J. \& Riley, P. W. (2002). The mcrA gene as an alternative to $16 \mathrm{~S}$ rRNA in the phylogenetic analysis of methanogen populations in landfill. Microbiology 148, 3521-3530.

Magee, C. M., Rodeheaver, G., Edgerton, M. T. \& Edlich, R. F. (1975). A more reliable Gram-staining technique for diagnosis of surgical infections. Am J Surg 130, 341-346.

Mangels, J. I., Cox, M. E. \& Lindberg, L. H. (1984). Methanol fixation: an alternative to heat fixation of smears before staining. Diagn Microbiol Infect Dis 2, 129-137.

Miles, A. A., Misra, S. S. \& Irwin, J. O. (1938). The estimation of the bactericidal power of the blood. J Hyg (Lond) 38, 732-749.

Miller, L. T. (1982). A single derivatization method for bacterial fatty acid methyl esters including hydroxy acids. J Clin Microbiol 16, $584-586$.

Millner, O. E., Jr, Anderson, J. A., Appler, M. E., Benjamin, C. E., Edwards, J. G., Humphrey, D. T. \& Shearer, E. M. (1982). Flurofamide: a potent inhibitor of bacterial urease with potential clinical utility in the treatment of infection induced urinary stones. $J$ Urol 127, 346-350.

Moore, L. V. \& Moore, W. E. C. (1994). Oribaculum catoniae gen. nov., sp.nov.; Catonella morbi gen. nov., sp. nov; Hallella seregens gen. nov., sp. nov.; Johnsonella ignava gen. nov., sp. nov., and Dialister pneumosintes gen. nov., comb. nov., nom. rev., anaerobic Gramnegative bacilli from the human gingival crevice. Int J Syst Bacteriol 44, 187-192.

Moore, W. E. C., Holdeman, L. V., Cato, E. P., Smibert, R. M., Burmeister, J. A., Palcanis, K. G. \& Ranney, R. R. (1985). Comparative bacteriology of juvenile periodontis. Infect Immun 48, 507-519.

Page, R. D. M. (1996). TreeView: an application to display phylogenetic trees on personal computers. Comp Appl Biosci 12, 357-358.

Pearson, R. M. \& Smith, J. A. B. (1943). The utilization of urea in the bovine rumen. II. The conversion of urea to ammonia. Biochem J 37, 148-153.

Preston, N. W. \& Morrell, A. (1962). Reproducible results with the Gram stain. J Pathol Bacteriol 84, 241-243. 
Skerman, V. B. D., McGowan, V. \& Sneath, P. H. A. (editors) (1980). Approved lists of bacterial names. Int J Syst Bacteriol 30, 225-420.

Theilade, E. \& Gilmour, M. N. (1961). An anaerobic oral filamentous microorganism. J Bacteriol 81, 661-666.

van Gylswyk, N. O. (1980). Fusobacterium polysaccharolyticum sp. nov., a gram-negative rod from the rumen that produces butyrate and ferments cellulose and starch. J Gen Microbiol 116, 157-163.

van Gylswyk, N. O., Morris, E. J. \& Els, H. J. (1980). Sporulation and cell wall structure of Clostridium polysaccharolyticum comb. nov. (formerly Fusobacterium polysaccharolyticum). J Gen Microbiol 121, 491-493.

Weatherburn, M. W. (1967). Phenol-hypochlorite reaction for determination of ammonia. Anal Chem 39, 971-974.

Willems, A. \& Collins, M. D. (1995). Evidence for the placement of the Gram-negative Catonella morbi (Moore and Moore) and Johnsonella ignava (Moore and Moore) within the Clostridium subphylum of the Gram-positive bacteria on the basis of $16 \mathrm{~S}$ rRNA sequences. Int J Syst Bacteriol 45, 855-857. 